\title{
FOREST MYTHS: A BRIEF OVERVIEW OF IDEOLOGIES BEFORE ST. STEFAN*
}

\section{Pavel F. Limerov}

\begin{abstract}
:
The article discusses forest and solar myths in Komi mythology in the era prior to Christening in the 14th century. After adopting Christianity the forest became to be regarded as the abode of heathens and dark devilish forces. In the medieval Komi calendar, the year was divided into two major periods - the elk season and the bear season, and into nine months, according to the season of hunting, and, the pagan religion. In the 19th century the Orthodox calendar had already been adapted to the hunting activities, and the agricultural activities had assumed the principal position in the southern areas of the Komi settlement. Folklore and archaeological materials provide evidence of the existence of at least two basic mythological systems in the prehistoric mythology of the Komi, one of which is connected with a calendar legend about the hunt on a Sun elk, and the other with a cosmogonic myth about a water bird extracting the earth from the bottom of the primordial ocean. The bronze pendants and metal clasps from Perm reflected the structure of the Universe, expressed in animal symbols. Particular groups of zoomorphic images in turn symbolized the structure of a ethno-social group, or the shaman's journey across the heaven to two heavenly keepers of the world. The article examines the widespread motives about Chudes, goddess with three faces and four breasts, Sun elk, Mother Earth, etc.
\end{abstract}

Keywords: animal symbolism, hunting calendar, Komi mythology, Chudes, Sami, solar myth, totemism, shamans journey, Earth Mother, Orthodox

K. Popov, who has studied the life and economic activities of the Komi population in the second half of the 19th century, has noted: "If it was considered necessary and possible to record the history of the Komi people, it would also be necessary to write a history of their hunting" (Popov 1874: 71). The subjunctive phrase "it would be possible..." expressing the author's doubt, is quite pertinent, especially as it is impossible to collect the written facts for a corresponding history. The author is convinced in something quite different namely, hunting was not only and not so much a means of economy for the Komi-Zyrians as a representation of their life and something that attributed meaning to it. Evidently, this view on the Komi way of life in the 19th century has been so standard that the Russian author A. V. Kruglov, who was familiar with the Komi language 
and culture has considered it possible to translate ethnic name komi vojtyr as 'the forest people' (Kruglov 1999). This misinterpretation concerns only the meaning of the word 'Komi', as at the time Komi were indeed the people of the wood, they remained so until that time, and are now in spite of the fact that they are no longer hunters. They will always remain the Komi people as long as they have their woods.

"The history of hunting" of the Komi people began at the time of distant antiquities when their predecessors were a part of the ProtoUralic people and inhabited the woods of Western Siberia and the Urals in the 9th-6th millennia BC. The Proto-Uralic people can be regarded as an ethnolinguistic community, once uniting the ancestors of the present Finno-Ugric and Samoyed people. They were hunters and fishers, who not only used the advanced technology of flint processing but also possessed analogues of all modern fishing tools. Archaeological findings discovered in peat bog at the Vis I site near Lake Sindor are a convincing evidence of it. So, in addition to the Mesolithic flint objects in the list of findings discovered by G. M. Burova, more than 200 objects of timber, tree bark, and grass have been found, including skis, sledge runners, oars, hoops, bows, arrows, clubs for hunting water-fowl. According to the found fragments, they knew how to make fishnets from sedge; they also had a stirring pole, manage, fyke traps, nets (Saveleva 2004: 20) all these things are also a part of a modern fishing equipment. The variety of objects is truly astonishing, including genuine rarities, such as a fragment of a ski, which one end is surrounded by an ornamentation depicting a sculptured head of an elk (Saveleva 2004: 20). Certainly, the utilitarian and aesthetic use of the figure would have to be ruled out from the very start: the ancient artists, though not unfamiliar with the concept of aesthetics, saw it as representing certain magical qualities. The elk-head on a ski, the quickest of all, most likely informed the hunter of the force and speed of the animal, which, already at this time, belonged among the particularly holy and worshipped animals. This finding is especially interesting as Lake Sindor is also known as the place were a hunter called Yirkap was defeated. He was a hero in a Komi legend, who had magic skis that took him wherever he wished at the mere speed of thought. 
In the 18th-19th century, the "three stage" hypothesis was current in European science. According to this theory, mankind in its evolution constantly passes from the hunter-gatherer society to herder society, and then to the agrarian society. Modern hypotheses, which are not sufficient for distinguishing the core from the periphery, assume that agricultural and herding economy emerged in complex form (Tokarev 1986: 244-245). Be that as it may, but in science at large the strong opinion on precedence of agricultural societies over hunter societies still holds. Transition from hunting to agriculture, i.e. from appropriating hunting-fishing to manufacturing is considered a cultural revolution, which has encouraged the emergence of civilizations. True, civilization mostly stands for cities and urban culture, but the hunting societies did not give rise to the emergence of cities. But can these societies be considered more primitive based on this claim only? Any type of manufacture, be it agriculture or cattle-breeding, presupposes exploitation of nature, and mankind needed strong enough measures to undo this violence against nature, thus, not without reason, one of the hypotheses claims that the transition to agriculture and cattle-breeding has been caused by the ecological crisis brought along by natural or anthropogenic factors (Tokarev 1984: 247). It means that only a part of mankind needs to address domestication as a means of survival and not because it appears more practical rather than the other part of mankind, which has remained deeply involved in the tradition of hunting. Incidentally, there are other hypotheses concerning the reasons for Cultural Revolution, but the problem is that the balance between human activity and the way of nature has been disturbed forever. Certainly, it had been disturbed already before, though quickly restored, as the activities of people were incorporated in the yearly cycles of nature and as such did not differ from the activity of other predators. Transition to agriculture meant qualitative changes in all spheres of human life; most importantly, it has brought along a general growth in the efficiency of economy, emergence of excessive production (Tokarev 1984: 334, 345), and population growth. In turn, it led to the further perfection of technological "know-how", and thus to man's increasingly greater isolation from nature.

Not less importantly, the transition to agriculture has also changed the types of intangible cultural genesis. From this point forward, 
the emergence and formation of spiritual culture - i.e. the mythology and religion of agricultural and non-agricultural societies - have diverged. This can be explained by the fact that in ancient societies manufacture and religious practices have been closely interrelated and even constituted a whole, which has enabled P. A. Florenski to conclude that there must have been a common "theurgical system" of manufacture and religion in ancient societies (Florenski 1976: 118). Transition to agriculture thus stood for a quantum leap from the theurgical system of hunting to that of agricultural. Probably around this time the agrarian calendar emerged, which was based on seasonal agricultural work, ${ }^{1}$ and was associated with mysticism of agrarian cults and holidays. Most importantly, the parameters of the religious-mythological concept of fertility changed. While it was characteristic of the hunting society to believe in heavenly mothers, who gave birth to working animals (Rybakov 1979: 10), the agrarian goddess-mother mostly ensured the fertility of plants and was identified with Earth Mother. Fertility cult was also associated to the myth of the cosmic marriage between the Heavenly Father and the Earth Mother: this motif was entirely unknown in the hunting society, which honoured not the Earth itself, but its "skin", its "hairy" surface, the woods that grew on the Earth. The list of divergences could be continued indefinitely, but the underlying fact is that, over the millennia, entirely different systems of conceptualising the world emerged on the basis of the agricultural and hunting traditions. Those who worshipped forest believed in the cosmic relationship of heavenly beings and earthly woodlanders, including deities, people and animals, i.e. they conceptualised the wood as the only natural living environment and sphere of economy, whereas the fertility cult of the Earth Mother necessitated the reclamation and cosmologisation of large wild forests, and their cutting down for the cultivation of arable lands.

The production of superfluous food has given agriculture an advantageous position, and favoured its expansion throughout the entire area of human settlement. Having settled in the Western Europe, the Indo-Europeans had mastered the agricultural works already by the 5th millennium BC, while the Finno-Ugrians, who had settled in the woodlands of Northeast Europe and had lived there since the most ancient times, in fact, continued to follow the hunters' way of life all through the Paleolithic period until the Middle Ages. This 
choice was further encouraged by broad and rich hunting lands, quite sufficient to provide subsistence for the few tribes, ${ }^{2}$ and also by the climate in the north, where agriculture could serve only as an additional way of subsistence. At the beginning of the Iron Age, in the first millennium $\mathrm{BC}$, in the areas of the most intensive contact between the Finno-Ugrians and Iranian and Turkic tribes in the south and the Slavonic, German, and Baltic tribes in the West, agriculture began to gradually prevail. Thus, the tribes of the Iron Age known as the representatives of the Ananin culture, the ancestors of the Komi, Udmurts, and partly also Mari, already had a complex system of economy in which hunting was combined with agriculture and cattle-breeding. However, according to archaeological finds of bronze cultic objects, characteristically zoomorphic in appearance, the mythology of Ananin people must have been centred on hunting worship. But already in the following epoch, zoomorphic bronze figures were discovered among the archaeological findings of the ancestors of Komi-Zyrians and Komi-Permyaks, whereas these were not known among the Udmurts, whose language is related to the Komi language, and also the Mordvins and the Mari. This suggests that by the beginning of the Middle Ages, independent cultural and mythological traditions associated with agrarian worship had begun to emerge and develop among the southern and western groups of Finno-Ugrians. At the same time, a considerable number of Finno-Ugric tribes which had settled on the vast EastEuropean plains remained hunting communities.

In middle of the first millennium BC, in the northern part of EastEuropean plains the Slavic farmers moved on in search of free land, and from then on the Finno-Ugrians enter the sphere of active cultural influence and even become an essential component of the developing Russian ethnos. It may be assumed that probably around this time the Slavs adopted several aspects of mythology associated with forest, such as a cosmogonic myth about a diving bird or the motif of the Master of the Woods, which still failed to prevent the alienation of agriculture from the forest. Even in the traditional culture of what had already become Northern Russia, superstitious fear for the elemental force of the forest continued to prevail throughout centuries. ${ }^{3}$ 
The opposition between the agricultural civilization and forest cultures strengthened after Europeans, and the Slavic people, adopted Christianity. The forest became to be regarded as the abode of heathens and dark devilish forces, in the "Northern Thebes", as the present-day Vologda Oblast is called, and this is where the unprecedented migration of the Eastern Slavs to the Finno-Ugric North, which later became to be called the "monastic-rural colonization", began already in the post-Mongolian epoch. The goals of the monks and peasants were principally different. While the former went in the woods as "hermits" to find peace in the solitude of the forest for living in ascetics and praying to fight with demons, the latter searched for deserted lands to clear it for cultivating land. Inhabitants of the northern areas fostered a Christian agricultural culture, which denied any association with people of the forest culture, little or not familiar with agriculture. The pagan Chudes, who had been the ally of the Eastern Slavs in the North from time immemorial and took very actively part in the ethnogenesis of Russians, was suddenly attributed demonic features. A medieval Russian author comments on the contact of these two cultures as follows: "The most ancient inhabitants of this region - the barbaric and foul raw meat eaters and white-eyed Chudes, who, having come to the shores of White Lake (Beloye Ozero) plundered the region: burned down the settlements, devoured adolescents and babies, killed the adult and the old in many ways" (Krinichnaia 1987: 83). Presently, it is impossible to adequately describe the manner how the colonization of the Finno-Ugric North took place, though some details of the "contact" can be presented quite confidently. Evidently, Russian peasants, who had settled in the floodplains of the northern rivers, were confident that these areas were unoccupied and uncultivated, as the land was not ploughed. It did not occur to them that these territories had been used for thousands of years, though only as hunting grounds. They could not see or understand the other culture, since they considered farming (agriculture and Christianity) the only possible way of life. Even though they had settled near the Chud settlements, they did not regard their neighbours as people before they converted to Orthodoxy and mastered the Russian agricultural tradition. ${ }^{4}$ The clash of the two cultures is somewhat reflected in the native legends about Chudes, which spread all over the Russian North - from the Kola Peninsula to the Urals. Despite of the broad distribution area of the texts, their plot is actually iden- 
tical: having been rescued from the occupants, a Chud buries itself in the ground or escapes by fleeing to the north. It is impossible to determine with any certainty the verisimilitude of how actual events are reflected in legends, but is true that in the medieval times, FinnoUgric tribes, who had settled in the Yaroslavl Volga region, the present-day Vologodshina, the areas around the White Lake, and the Northern Dvina and the Vyatka river basins, had disappeared entirely from the ethnic map of the world by the 16th-17th century. Only these Finno-Ugric peoples, who had adopted Christianity before the beginning of the large-scale rural colonisation, i.e. the Karelians and the Komi, and also these who became involved in agricultural activities already in the ancient times and developed a corresponding religious ritual system, i.e. the Baltic and Volgaic Finnish, escaped the fate of the northern Chudes.

As to the Komi, they converted to Orthodoxy in the 14th century, thus abandoning their original hunting culture, let alone religiousmythological tradition. Certainly, it did not occur in an instant but has evolved in the course of a long process, probably over a few centuries. For the Komi, the tragedy of Christianisation lied in that the conversion to the new religion meant the barely revolutionary substitution of one theurgical system of an autochthonous religion, i.e. the hunting practices and eventually also the worldview, with another. The stable life established over thousands of years changed into a new one, while this new agricultural way of life, which did not evolve from within the society itself but was introduced externally, was adopted. Probably, it was the Russian Orthodox way of life, which probably, exerted its influence on the assimilated FinnoUgric tribes.

There, on the site of the old settlements, or next to the Chud settlements that have been there since the 15th-16th century, new fortified towns and country churchyards were erected and the few Christian Komi started to build (Belitser 1958: 148). Whoever takes a look at it is left with an impression that the new settlements have been created from scratch, according to the Russian model, as if no Komi settlements had existed before this time. It is not a coincidence that in legends about Chudes there emerges a stable motif representing the opposition of the pagan Chud dugouts and the small log houses of the Christian Komi. It is almost as if those who 
had refused to become Christianised were not allowed inside the (Christian) peasants' houses. The Christian settlements were surrounded by fields, pastures, and hayfields, and the settlement started to look like a typical North-Russian farming village. The Orthodox belief provided a religious justification for the agricultural activities, which used to be associated only with hunting, and also offered a new calendar which followed the yearly farming cycle. Hunting was as if abandoned from amongst the basic forms of economy, which was radically at variance with the former theurgic culture of the Komi. The point is that the chronological system of the ancient Komi, and thus also their rhythm of life was basically different from those of the Russians. In the medieval Komi calendar, year was divided into two major periods - the elk season and the bear season, and into nine months, according to the season of hunting, and, most importantly, it was approved by the pagan religion (further on this subject see Konakov 1990).

This resulted in a unique situation of dualistic beliefs, in which the villagers who were engaged in agricultural activities lived according to the Orthodox calendar, whereas men, who were engaged in manufacture for the major part of the year, followed the pagan hunting calendar and performed pagan rituals. Even in the 19th century, ethnographers and journalists pointed out that a Komi is a Christian in the village and a pagan in the woods. Certainly, in the 19th century, the state of the Komi religion was no longer unequivocally dualistic, and by this time the Orthodox calendar had already been quite successfully adapted to the hunting activities, and the agricultural activities had assumed the principal position in the southern areas of the Komi settlement. According to the available data, by this time agricultural customs and feasts, such as for example, charla rok (a harvesting festivity, literally, 'the sickle porridge'), not to mention the Orthodox church holidays or the twelve main holidays, enjoyed a considerably more important sacral status in comparison with the traditional ritual of "sending off the ice" (the beginning of the drifting of ice in spring) or the day that marked the beginning of a hunting season (further on this subject see Konakov 1993). Transition to agriculture of life inevitably led to changes in the value system of the Komi people. The theurgical value of hunting gradually disappeared, leaving room only to its industrial applications. Konakov marks that by the 19th century 
the Komi had abandoned the taboos of excessive hunting owing to the loss of hunting morals. For the sake of a profit, the most valuable breeds such as sable and beaver had been extinguished, thus the last sable in the Komi territory was spotted by the Komi hunters in 1871; also, the number of hoofed animals, such as deer and elk, decreased dramatically (Konakov 1999b: 80). Nevertheless, the pagan hunting religion brought along the establishment of various restrictions for the protection of wildlife; these are followed until the present day, when the cutting down of forests, where the Komi have traditionally resided, and the actual abandonment of agricultural activities, which have formerly secured the continuance of the Komi people, appear to be under threat.

By time they were converted to Christianity in the 14th century, the Komi had developed quite an advanced religious-mythological system, which had its roots in the elk and deer religions of NorthEurasian hunters in the Upper Paleolithic and Mesolithic period. This claim relies on the similarity between a medieval Permian shamanic metal clasp of zoomorphic shape and the Stone Age cultic representations discovered in Northeast Europe, Western Siberia and the Ural region. These are the petroglyphs of waterfowl, bears, elks, carved in rock in Karelia and the Urals by primitive artists, the sculptural images of heads of elks, carved from wood or mammoth bone, wooden ladles, which handles are carved in the shape of waterfowl heads, and many other things - all this, as a whole, serves as an evidence that the people and tribes who occupied such a vast territory over thousands of years actually shared common mythological motifs. The people, to whom the mythology associated with forest was inherent, and who not only shared a common language and analogous cultural traditions, also shared hunting as the general cultural-economic form of society.

Now it is already difficult to reconstruct the pre-Christian religion of the Komi more or less in its entirety; nevertheless, it is possible to reconstruct some of the most general motifs on Chud icons and compare these against the mythology of other peoples. No doubt, these representations, which according to academician B. A. Rybakov are "densely filled with relief carvings representing half-men-halfelks, heads of elks, scaly animals, wild furry animals and birds" (Rybakov 1979: 10) were used in cult worship. Since the late 19th 
century, many hypotheses have been posed on the semantics of images represented on the metal clasps, but recent authors have agreed that the metal clasps of the Chuds represent the cosmological beliefs of the ancient Komi.

In the 1960s, ethnographer V. V. Charnolusski compared the Sami totemist myths with the motifs represented on the Perm icons and has found interesting conformities. One of the central images in Sami mythology is Mjandash-parnj - the human deer, forefather of the Sami, who is also regarded as the cultural hero, who has taught the people the ritual hunting of deer while wearing deer antlers (Charnolusski 1965: 101-130). Some Charnolusski's findings have been recognized as accurate by academician B.A. Rybakov, particularly his "comparisons of images of seven souls (the seven stars of the constellation of elk) and the recorded accounts of "young deer" falling from the sky (Rybakov 1979: 10).

The interpretations have been generally regarded with caution, as can be seen, for example, in V. J. Petrukhina's argument claiming that "from our point of view, the Perm zoomorphic representations convey their own pictorial "language", which is difficult to translate into the "language" of the Sami mythology. Clearly, the "language" of the animal representations is the same than the "language" of cosmogonic myths, and it is no coincidence that its central image - the cosmic elk, totemist forefather of the Sami people - has assumed the features of an elk and a human" (Petrukhin 2003: 191). The hypothesis about the interrelation of cosmogonic representations and the symbolism of totemist tribes was actively supported by L. S. Gribova, who argued that the composition of a figurative representation basically reflected the structure of the Universe, expressed in animal symbols. Particular groups of zoomorphic images in turn symbolized the structure of a totemist ethno-social group (Gribova 1975: 12-24).

Rybakov has interpreted the pictorial language of the Perm images by comparing them against the mythology of the western Evenks (formerly known as the Tungus). Rybakov has focused his attention on the motif, where the central characters are "a lizard-like animal, a male human figure in a headdress styled as the muzzle of a female elk and two female figures with hooves, heads of female elks, located on sides of the figures in such a manner that the muzzles of 
female elks form a semicircle, closing above and forming, together with the lizard-like animal, as though a frame for all the central images" (Rybakov 1979: 12). He explains the motif with a myth known among the Evenks, Nganasans, Dolgans, etc. concerning the shaman's journey across the heaven to two heavenly keepers of the world, who are "half-women, half-elk (or deer), whose will determines the hunting luck for the tribes, the offspring of deer" (ibid: 14). The human elk, being the central figure and wearing the shaman's clothes, represents one discovered from a Mesolithic Olenii island burial at Lake Onega, and the figure is depicted as wearing a headdress with a mammoth's tusk, which imitates the antlers of a female elk. Interestingly, two female skeletons were found on either side of the man's body in the same burial (ibid: 15), laid there as if according to the interpreted figure. The lizard-like animal, on whom the shaman stands, symbolises the mythological underworld, its representation with mouth agape towards the west suggests that its function was to swallow the sun-elk on its westward course. The frame consisting of the adjoining muzzles of the two female elks and the lizard-like animal symbolises the firmament. The middle world is represented by paired images of men and women, sometimes families with a child, and also various animals and birds. The man-elk standing on the lizard-like animal represents a shaman travelling through the worlds of the universe, sometimes it has wings instead of hands to fly with birds, and an eider is depicted on a metal clasp placed at the side of the shaman, probably used for travelling to the underworld. The solar myth, which motifs are on the metal clasps, is represented variously: a) circular sun with a female mask which is framed with the muzzles of the two divine female elks from above and the two-headed lizard-like animal marking the solar circulation from below; b) the Universe is surrounded by the world river, a two-headed lizard-like animal, below which female elks oriented from the east to the west and a solar disk in the centre are shown; the mouth of the lizard-like animal oriented westward swallows the head of the female sun elk; c) the third variant of the solar myth is presented by the image of a huge bird with a solar mask on its torso and the small lizard-like animal on the bird's tail in the background (ibid: 13-19). We should recognise A. S. Sidorov, who at the beginning of the 1920s hypothesised that the image of the human-elk riding the lizard-like animal represents the solar myth which is retained in language in the form of expres- 
sions like шонді гӧн ньылыљ 'on the wool of the sun', or 'against the sun' - шонді гӧн пужыд, 'against the wool of the sun' (Sidorov 1972: 12-13).

Another observation by Rybakov concerns the image of two world rivers in the mythologies of the Siberian people, which corresponds to two kinships of a dually organized society. On the Perm figures these two rivers are shown in the form of two vertical streams running from the muzzles of female elks constituting a firmament above to the underworld represented by the muzzle of the lizard-like animal (Rybakov 1979: 20). Rybakov concludes

The Universe consists of three worlds: the underground-underwater world personified by the lizard-like animal, who swallows the sun (represented by the head of Heglen, the sun elk), the middle world of people and shamans, and the upper world of heaven, where the shamans obtain their magical powers from the masters of heaven. The sky is represented in the form of two female elks, whose muzzles form the firmament; shamans with wings fly up to this firmament, from which the world rivers run down to the underworld of the universe (Ibid: 21).

It is difficult to disagree with such a reconstruction of the mythological worldview of the Permyaks. The upper world is often symbolised by representations of birds or birdlike creatures with dogs heads (griffins), and the lizard-like animal, as the symbol of the underworld is sometimes replaced by some other mythological characters like beaver, horse, arachnoids, sometimes even bears and elks. In some compositions of figures, "the world rivers" are replaced by the figures of snakes, which is generally consistent with cosmological semantics of metal clasps as the latter symbolise the mythological water. All the images are static, because, with an exception of some, they always correspond to their position in the cosmological system, and their symbolism is consistent. The central figure on these compositions is an altogether different matter. If it symbolised the middle world, it should have been depicted as a zoomorphic figure as an embodiment of the earth, most probably, as a female elk, and, furthermore, it should have been static. However, this is not the case - on the contrary, the central figure of compositions is always dynamic. The character is able to move, its posture expresses movement: it either travels on the lizard-like animal, moves in time (the 
composition of three female sun elks on the back of the lizard-like animal, while the fourth is swallowed by the lizard-like animal, represents the same elk at different time), or flies by means of hands or wings. Despite of this, the choice of particular characters as central figures is less important: the central figure is often a human elk, a travelling human elk or a female deity. It seems that the central image reflects a certain mythological plot, which is not only known to the users of the sacred figures, but is also considered important in the religious-mythological context. This might be the only reason why the limited number of the central images could have so many different mythological meanings; the half-man-half-elk, for example, represented both solar as well as shamanic legends. Speaking of the latter, it is worth emphasising that that the hero of a shamanic myth must have been a deity, and not an ordinary human, even though he might have been a shaman. Therefore, the elk-head above the figure of a human-elk is not some ordinary headdress but a symbol of the character's divinity. The character is either a divine forefather, like the Sami Mjandash deer, or a mediating deity like the Ob-Ugrian Mir-Susne-Hum or Ket Doh, who is considered the first shaman. In the course of a ritual performance, a wise man who could also serve as a shaman, exposed the qualities of the deity and imitated its actions.

Events of mythological significance would take place only in the centre of the world, on top of the World Mountain (Tree). From this frame of figures represented as the world river or two snakes, which symbolize the waters of the primordial ocean from which the said world mountain of the future Earth has risen in a cosmogonic myth. These images constituting the frame can be read on a horizontal plane, which symbolises the periphery of the Universe, whereas the central figure can be read vertically. Even if considering the conventional dimensions of analogous representations, the dimensions of the central figure of this composition appear gigantic relative to the representation of the universe: the central figure tramples on the chthonic underworld-lizard, with its head touching the firmament represented by the figures of the upper world. Consequently, the body of the central figure as though connects all the levels of the Universe which, actually, is also reflected in the structure of its body: as to the lizard-like animal, the legs correspond to the mythological underworld, and this is why the legs of a female 
deity on analogous figures are sometimes depicted as bear paws; the torso corresponds to the earthly world, and the head - to the upper world, which is why solar symbols are depicted on their heads, such as the circular figure on the forehead of the female deity, and the elk head above the human figure, which can also be interpreted as a solar symbol.

The best description of the figure of a female deity undoubtedly originates from Konakov, who has written:

Its universal nature is emphasized by a solar sign on her forehead or the anthropomorphic symbol of the sun (in the form of the female figure) directly above her head. Its association with the animal world is revealed by the existence of zoomorphic features: the figure has elk hoofs and bear paws instead of feet and hands, bear paws instead of feet and bird wings instead of hands or arms. On one figure the claws on the bear paws - or feet of the female figure disappear into the subterranean stream and at once reappear on the surface, with anthropomorphic plants emerging from them. Thus, the given ancient Perm deity had a wide range of important functions. The goddess, undoubtedly, with its high position in the mythological hierarchy, personified the earthly world. It connected together the underworld and the upper sphere; was directly related with the sun's life-giving power (solar symbolics), water, and the fertility of earth, and, thereby also the vegetative world. The zoomorphic features of the goddess are borrowed from the most brilliant and powerful representatives of the fauna of all earthly spheres: a bear, an elk, and diurnal predators of the Aquiline family, which symbolises its supremacy over all fauna. The figure of a human mask depicted on the chest of the female figure enables to assume that it also knew about the reproduction of humankind (Konakov 1996: 60).

There was no name to refer to the female goddess in Komi mythology, therefore Konakov names her Earth Goddess (ibid: 60), which may be identified with the wife of the Finnish sky god Ukko, the Estonian Maa-ema, the Sami Mader, the Mordvin Moda ava, and the Mansi Kaltasch-ekva (Aikhenvald, Petrukhin \& Khelimski 1982: 189). This list is typologically accurate, even though several other names could be added to it, the point is in something else: the religious forms of worshipping the Earth Mother are characteristic of 
agrarian cultures, for example, people of Indo-European origin, who developed agrarian worship in at least 5th-6th millennia BC (Nikolaeva \& Saffronov 1999: 157), therefore, the forms of Earth Mother worship among the Finno-Ugric tribes cannot be considered very ancient. Considering that their religion was based on hunting, it is actually not a coincidence that the Komi do not even have a linguistic equivalent for the concept of Earth Mother, though a goddess Muzjem Mumy - the Earth Mother - is known in the mythology of the Udmurts, whose language is related to the Komi and who were largely an agrarian people.

Famous historian of religion Mircea Eliade (1999: 136) has also written about the total absence of the myth, generally characteristic of agrarian cultures, concerning about the sacred marriage of the heaven and earth among the Uralic-Altaic people, which defined the idea of fertility of earth, in relation to that some of these peoples also called heaven the "Father", and earth the "Mother". It should be added that even such widely quoted epithets of the ObUgrian earth goddess Myh-anki as "the skinny earth", "the woolly earth" (Golovnev 1995: 534) speak about the "external" aspect of the earth rather than its fertile womb; the goddess emerges as the wife of Myh kon, or the god of the underworld. It is quite logical: for people, transmitters of the hunting-fishing culture, among whom belonged also Finno-Ugrians, the myth about fertile roles of the Earth Mother could not be of great importance owing to a different type of economy which was dependent on other, more specific factors for the forest people, as these ensured the continuance of the tribe and provided opportunities for hunting animals and birds.

At the same time, the ancient Uralic myth about divine fertility has been evidently documented in manuscript sources

Even our old men went beyond Yugra, and the Samoyeds, as they witnessed in the northern countries: a huge cloud spread and from that new cloud young fibres were first born, they fall down and spread on the earth. And there is also another cloud and small deer fall down and grow up and spread on the ground (quoted from Rybakov 1979: 10).

Rybakov correctly associates the text with the mythological motif of the divine female deer (elks), who give birth to deer for earthly 
herds, and this determines the success and continuance of the hunting tribe (ibid: 14). In other words, for the peoples of North-Eurasia, the mythological fertility does not have an earthly origin, but descends from the heavenly spheres. In the Finno-Ugric mythology, it is represented by the motif of the descent of heavenly goddesses or animals to the earthly world. Such is the Finnish world maiden Ilmatar, who entered to the waters of primordial ocean to give birth to the future creator of world Väinämöinen; such is the Ob-Ugrian Kaltash, the giver of life, who was pushed down from the sky by Torum and gave birth to Mir-Susne-Hum in the air, between heaven and earth (among the Karelians Kaltas-san-taaram - Kaltas is the heavenly mother, quoted in Ignatov 2004: 101); such is the Mordvin Ange-Patjaj, who resides in heaven and gives life on the ground. The myth about a heavenly maiden is known in the mythology of the Sami, Estonians, Mari, Komi-Permyaks, where the idea of fertility is probably less pronounced. As to North Siberia, there are a number of goddesses - the Old Women of Life, who reside in the heavenly world somewhere in the south: the Selkup Yljunda Kotta, the Nganasan Ninulemy Mou njamy, the Ket Tomam, and the Evenk Bugady Enityn. All these divine characters give fertility of earth but reside in heaven. Next to the mentioned female deities, there are also others, including the Earth Mother, but the functions of all of them are secondary.

As to the goddess on the lizard-like animal, her iconography presented solar and zoomorphic symbols, which signify her animal fertility in the heavenly spheres, and the symbolism of plant fertility is virtually missing. There is no doubt that she may be regarded as belonging to the category of female deities known as the Great Mothers, but she is more likely Artemis, the goddess of wilderness, rather than the Gaya, the Earth Mother. The representation of this goddess might be associated with the famous representation of Zarni Anj - the Golden Woman, whose worship was first mentioned in Nikon's manuscripts in a report about the death of St. Stephen of Perm (Konakov 1999a: 159). This is suggested by the use of the epithet "golden" which is attributed simultaneously both solar and chthonic values, and which characterises the way the Mother Goddess is represented owing to her functions of giving birth, which was considered important also in the solar-heavenly upper world as well as the chthonic underworld. 
On the Chud images there are figures of goddess with three faces and four breasts, which serves as an evidence that she was related to all the three spheres of the universe, whereas the four breasts symbolize her function of feeding all the four aspects of light. According to a legend, four breasts were given by the sky god Jen to the female warrior or heroine (bogatyr) Dzudza, the progenitress of the Zuzdin Komi-Permyaks, so that she would be able to feed her six hero sons - bogatyrs (Petrukhin 2003: 216). An analogous myth was also known among the Ob-Ugrians, who believed that Torum had sent his six sons to the earth to handle human affairs. They were settled on the river $\mathrm{Ob}$ and its larger tributaries and became the ancestors of six major tribes - sir, the sons-bogatyrs, separated from their fathers and, in turn, became the founders of smaller tribes settled at the tributaries. Apparently, the Zuzdin text echoes the ancient ethnogenetic myth which was known not only among the small ethnic group of Zuzdin-Komi but also among all the Komi. Evidently, the father of these six bogatyrs, who became the founders of six cities, was Jen itself. Like in the Ob-Ugric tale version, the six brothers became the progenitors of six major tribes from whom all the other tribes were born later on. The idea of analogous myths is in that they attributed meaning to such a universal organisation, which is constructed according to the principles of a family: the progenitors are the Heavenly Father and the Goddess Mother, their sons become divine progenitors, their grandsons - heroes or founders of separate ethnic groups, and the great-grandsons and the greatgreat-grandsons constitute mankind and inhabit the populated world.

Thus, the entire world is in fact a collective body of deities and mortals, where the relationship between the gods and people are based on the principle of kinship ties: the divine gods-parents, their children and grandsons as ancestors of groups of people, who regard mankind as their grandsons. Similar relationships can be observed even now among the Ob-Ugrians. In the medieval period, it was the most characteristic worldview of the Finno-Ugrians, traces of it can still be found in the modern ancestral cult. The ancient Perm figurative art includes figures of a "family", depicting a man and a woman with a child in the middle, standing on a lizard-like animal. It is dubious that the medieval artist condescended to depict the figure of human pair: instead, this is a representation of 
the divine family of progenitors in their universal importance. Within the context of a universal family, the divine pair is not simply an embodiment of male and female symbolism, but is attributed the meaning of the universal fatherhood and motherhood.

The concept of divine fatherhood did not inspire special worship owing to the mythological indifference of the sky god in earthly matters, therefore in the male lineage the important object of worship was one's sons' being good warriors and hunters. As to the ObUgric mythology, the achievements of a divine progenitor (proprietor of hereditary land) in battle constitute a significant part among the entire corpus of analogous sacred texts. On the other hand, the wife of the sky god, who descended (dropped) from heaven to the earth, emerges in all spheres of the entire earthly world, including those of human and nature. Such is the Ob-Ugrian Kaltash (Anke Pugos of the eastern Khanty): next to its human shape, it can appear in shapes of a female hare, frogs, a swan - all these shapes are considered equal to humans. All his divine sons and grandsons appear in various zoomorphic shapes, and some animals are divine by birth. The Great Mother of gods is the guardian of birth of all live creatures including humans, and it could not be in any other way: the sphere of nature and humans both originate in her divinechthonic womb. In other words, all animals, birds, plants and humans are interrelated by kinship ties. Of course, in such a mythological system, the function of hunting cannot be simply to obtain food, it is always a ritual theurgical act, the purpose of which is purification of soul of the killed animal, and its departure to the domain of the Mother God for a subsequent reincarnation. It is possible that in a specific archetypal variant of the ritual, the hunter functioned as the shaman (or, indeed, was one), reaching the unfamiliar and invisible sphere of the Mother Goddess to ask permission to hunt. Also, it is not impossible also that for this purpose the hunter-shaman entered into the sacred marriage with the Mother Goddess or with a female forest spirit. Anyway, the motif of the marriage of a hunter and a forest woman is one of the most widespread ones in Komi folklore. As a rule, the forest woman appears in the hunter's hut in the form of his wife, conceives his child and disappears upon the hunter's return home after work. The age of the motif confirms the fact that it was also known in the folklore of other Finno-Ugric peoples. 
Erotic motifs occur frequently in the late mythological texts associated with the forest theme. There are bylichkas ${ }^{5}$ about the meetings of hunters with forest spirits who appear in the shape of a maiden or a woman, and there are also texts of various genres concerning the marital relationships between women and forest spirits who appear in the shape of a man or a bear, a frequent shape for a forest spirit. The way the consequences of such relationships are described depends on the genre of the text: in bylichkas the child born from such a union is particularly ugly, in legends, where the more ancient motifs have been retained, it often becomes a hero. Therefore, the Komi-Permyak hero Kudym Osh has been born from the marriage of his mother and a bear, according to one narrative version, warrior or hero (bogatyr) Pera was the son of a bear, according to another he was born from Parma (Forest) in the times of yore. In the same legend, Pera marries the Sun's daughter and becomes the ancestor-progenitor of the Komi, therefore it is possible to associate, without any specific common features, of Parma, the hero's mother and the female embodiment of the forest to the concept of the Goddess Mother. Meanwhile, the idea of a female deity as an embodiment of the forest can be inferred from the ritual verbal formulas recited while entering the forest: "If you go to the forest, it is necessary to ask permission from the Forest-Water (Komi vör-va), to ask mother Forest-Water to allow you in the forest". ${ }^{6}$ In modern Komi language the word vör-va means 'nature' and is considered a neologism, whereas the word has also a more archaic meaning, in which it is known in folklore texts.

Konakov has correctly assumed that the most ancient name of the Goddess Mother may be derived on the basis of names of a Turkic goddess Djer-su (literally, the Earth-Water) "the Sacred Earth", however, the lack of evidence has not enabled him to provide a complete characterisation of this goddess (Konakov 1996: 60). For the ancient Turks, "earth" and "water" are two key concepts for interpreting the world around them, or the mythological middle world, which is inhabited by people; for the Komi the two concepts of equivalent significance are "forest" and "water". To put it in other words, in the Middle Ages the concept vör-va could actually stand for the entire middle world, the personification and guardian of which was the Goddess Mother. As mentioned previously, it does not mean that her role as the guardian of the forest limited her 
scope of guardianship to hunting in forests only: the concept of female fertility is associated with her as well, which, in turn, indicates that this concept also originates in the forest. The Goddess Mother was also the patron of female crafts and household chores, as can be evidenced from the solar signs on distaffs, looms, and other traditional women's tools. Moreover, there is no doubt that she was the guardian of the fertility of domestic animals. This is particularly true of cows, whose sacral status in relation to other animals in the Komi ethnic culture is relatively high. It is believed that Christ was born in a cow's manger, and cows were particularly associated with Virgin Mary. Traces of pre-Christian accounts can be also found in a text by G. A. Startsev, which was recorded in 1917. The text describes how cows were once milked by men, since women were not trusted for the job, and the cow was milked by using one hand into the palm of the other hand, and then the milk was drunk. A cow ran away once. The search of men was in vain but the housewife met a woman in the forest, who claimed to be the protector of cows against "evil forces", and taught the housewife how to take care of cows and gave her the sole right to milk the cow and take care of it (Startsev 1924: 118). In this sense the "the right of women" to take care of cows is actually no different than the materialisation of the sacred relationship between the woman and the Goddess Mother depicted on the figures of the Mother of God and the protector of the cows. Through the cow and its keeper the entire family was given the divine blessing. The tradition of leaving offerings to the deity of the forest, though performed less explicitly, was followed until quite recently. A good example here would be an extract of a recent mythological text:

My calf once ran away from the shed, could not catch it, that small calf, jumped and ran straight into the woods. Well, all right, son with a gun, with cords, went to the forest to look for it, we are thinking that may be [we] will have to shoot it. But the grandmother tells us, "I, too, will come with you". Came and spoke: "You have to take along gifts for Forest-Water in the place where we are going". Later she says to me: "Anna, did you take something along with you or not? The calf ran off, so we have to give something to Forest-Water [Komi vorr-valy]". I reply: "I did not take anything" - I had too little time for this. "But look, I got some red wine, and took it along". She took the wine, poured into a hole, we 
are standing and watching, and it all came back to us, and the calf came running to $\mathrm{us}^{\prime}{ }^{7}$

It is known that in the Christian era the concept of Goddess Mother merges with the concepts of Virgin Mary and Paraskeva Pjatnitsa. ${ }^{8}$ I do not dare to propose a date when the mergence of these concepts might have taken place - probably, sometime at the beginning of the Christian era. The Komi adopted these concepts already from the eastern Slavonic peoples; therefore, to find traces of the ethnic Komi tradition in these is probably impossible. It is impossible, because the Komi Christian culture is secondary; in fact, as it is based on agriculture, and follows an agricultural Orthodox calendar, it may be considered a variant of Russian Orthodoxy. In this light the conception about the female deity appears alienated from the forest, and is completely assimilated with the conceptions about Paraskeva and Virgin Mary. It was probably a long process, which intensified over the centuries, and more elaborate analysis will reveal additional information about the local characteristics of the cult of Virgin Mary in the northern Komi areas.

The function of a Heavenly Mother of the female deity standing on a lizard-like animal is marked by solar symbols - it may be a circle on her forehead or an additional female mask above her head, and sometimes even a mask on her chest. The Goddess Mother may have also functioned as a solar deity, and possessed an epithet Shondi Mam 'the Solar Mother' (cf. the Udmurt Shundy Mumy 'Sun-Mother') as sun is one of the symbols of heavenly and underworld fertility. In prehistoric mythology she may have been depicted as a female elk, which was known as the personification of the sun ${ }^{9}$ and this zoomorphic conceptualisation of her as a female elk has been associated with the legend of the cosmic hunt, which is to some extent known among many Siberian peoples. In Finno-Ugric folklore the motif of chasing an elk or a deer, even if only on very general terms, was also known. In most of these legends, a mythological hero chases a deer, which is attributed many exceptional qualities: beauty, size, unusual colour, or golden horns. Having caught the deer, the hero became a ruler of the country, found wealth, glory, often after marrying the deer after it transformed into a beautiful maiden. In Komi folklore, this motif is included in a legend about hunter Yirkap, the name of whom already alludes to paganism. He chases a blue deer 
on his magic skis made from as pu 'his own tree'. ${ }^{10}$ Such a tree possessed magical properties, and a thing made from its wood was also magical. Once a certain sorceress, who planned to destroy the hero, hid her daughter into the magical blue deer, counting upon that Yirkap will chase it god knows where and will not return too soon. The sorceress proved wrong, as the blue deer arrived instantly at the Siberian Rocks (i.e. the Ural Mountains), and the hunter came right behind on his magic skis. The deer turned into a beautiful maiden, who promised to become his wife, but the severe hunter did not believe the werewolf's words and shot an arrow towards her.

In European folklore, similar motifs of deer hunt are often connected with the motif of a wedding, as, for example, in Kalevala, where the pursuit of elk Hiisi is one Lemminkäinen's tests before his wedding. This is not a coincidence, because wedding is included among the prehistoric beliefs that used to be associated with deer (elk). In Evenk mythology, an ancient connection between the motif of chase, the mythological conceptualisation of the world and the symbolism of kin relations in a society has been noted. The legend describes how a bogatyr-hunter Mani, on his magic skis, chases the elk with an elk calf. The female elk has fled to the firmament of the taiga of the upper world, and the hunter has chased her to the sky. The chase in the heavenly taiga lasted for an entire day, during which the elk travelled across the sky from the east to the west, following the course of the sun. And upon his descent, the hunter captured the elk and has astounded it. But this did not end the hunt, because the elk calf managed to escape behind the horizon, and the next morning the elk calf, which had grown up over the night, appeared in the east, and the hunt started all over again. The hunter Mani remained in the taiga of the upper world for eternity and became a sky god. In a more archaic version of the legend the hunter is replaced with a bear called Mangi. In the Evenk cosmology the given motif is extremely important, as the elk symbolised the sun for the Evenks, and its daily slaughter by the cosmic hunter explained the daily cycle of the change of day and night (Anisimov 1959: 15-19). ${ }^{11}$ Representations of a bear and elk are also depicted on Neolithic petroglyphs on the rock surfaces in the Urals and in Karelia, and on Mesolithic tool handles with elk heads, discovered in various places: at Lake Onega, on Olenii island, in the Barents Sea, and in 
peat bogs in the Urals. More recent representations of elk and bear have been discovered on bronze pendants and metal clasps, and sometimes, the bear and the elk are depicted as fighting. On a bronze hunting calendar of the ancient Komi, the figures of bear and elk symbolised the periods corresponding to the spring-summer seasons, and autumn-winter seasons (Konakov 1990: 15). Konakov's research of the symbolism of hunting calendar indicates that the legend of the cosmic hunt represents the most ancient code of a zoomorphic calendar in Northern Eurasia. The symbols of bear and elk (ungulate) express mythopoetical view of the change of day and night, and the turn of seasons. "Within the zoomorphic code, the active beginning (spring, man's productive ability, destructive tendency) is personified as a bear, whereas the passive (autumn, the beginning of women's creativity, the idea of sacrifice) stands for a female ungulate (Konakov 1990: 19).

As to the Evenks, their cosmological system followed a three-dimensional structure in which the upper world (ugu-buga) was associated with the cosmic elk Heglen, who escaped its fate in the thicket of a heavenly taiga, and which became visible at night to people in the constellation of Ursa Major; the middle or earthly world dulugu-buga was the abode of people, and the underworld hergu-buga was inhabited by ancestors, evil spirits and mammoth seli, which is the counterpart of the cosmic elk in the underworld. The legend of the cosmic hunt was simultaneously a legend about the cosmic wedding in which the killing of the elk was interpreted as the marital relationship between two supreme deities: the sky god personified as a bear and Bugada Enintyn 'concerning their universal mother', who appears in the form of an elk as the mistress of the world, the mother of animals and people (Anisimov 1959: 21-22). The mythology of the cosmic hunt-wedding is based on the symbolical division of the Evenk society in two exogamous parts: the union of an elk and a bear tied together by marital and family relations, in which sense the legend embodies the archetype of such relations, and also the cosmic guarantee of their stability. Every year, the men of both kins performed a ritual struggle impersonating a bear and an elk, which result determined the supremacy of one kin for the next year. The kin or family elder was selected from amongst the winners (Anisimov 1959: 53). A reflection of similar motifs can be found in a Komi-Perm legend about a bogatyr-pam ${ }^{12}$ 
Kudym Osh, or Bear Kudym, who proposed marriage to a farway Vogul princess Koste, who had worn an elk mask since she was born, and even her father did not know about it. Thus, after taking a bath before the wedding, Koste's elk appearance vanished and she appeared before the father and wedding guest not as "the ugly bride", but as an exceptional beauty, and there was no end to the astonishment. It is remarkable that Kudym himself was born from a marriage of a bear and his mother, sorceress Pövsin 'One-Eyed'.

The images of bear and elk are two the most ancient symbols of male and female origin, and echoes of this symbolism can be traced in traditional wedding ceremonies, in the various texts of which the bride is referred to as "deer", "calf", her life is "solar", the party of the groom in laments for the bride assumes the shape of "bears", "cloud of thunder", and after the wedding, the bride's father-in-law and mother-in-law meet the newly-married couple wearing fur coats inside out, thus impersonating bears. The same symbolism can be encountered in the famous "Tatyana's Dream" in Evgeni Onegin by Pushkin: Tatyana, having escaped from a bear chasing her, arrives at a log hut; in the hut, the wedding table is laid, at which his soonto-be groom Onegin is sitting. In a recently published book on FinnoUgric mythology some light has been shed on the more ancient variants of the bear wedding: in a burial of one of the Yaroslavl kurgans, archaeologists have discovered the remains of a bear paw with a silver ring with carnelian inlay in its finger. Two women were interred in the tomb and the burial of a girl of 11-13 years near one of them has proved a unique discovery. Researchers have speculated that it is the earliest evidence of the widespread mythological motif about a marriage between a bear and a human girl. It is not a coincidence that the girl has been betrothed with bear after death: people at that time died early, and those who died before they reached adulthood, became the most fiendish of evil spirits after death. Therefore, to prevent the return of such spirits into the world of the living, the girl had to be "married" to a "groom" from the forest (Petrukhin 2003: 56-57). Allusions to the bear wedding can be found in ethnic folk tales about the girl and bears, heard in the childhood, however, in 1925, a news piece about an actual recurrence of the mythological wedding 
In the Voronje Pole village in Olonetsky province, old men spoke that peasants, in despair over the endless attacks of bears on their cattle, decided "to solve it with a girl", i.e. to give the bear a girl for the wife, and, as old men said, "it was important, like our grandfathers did in their time, to give the most beautiful girl”. They cast lots, and the lot fell on a Nastia. She was dressed up as a bride, wearing a wreath on her head, and was dragged into the woods. Sent her off with special recitation: "Do not condemn, Nastiushka, make the bear happy. Speak for us, nurse, do not let us be destroyed in fierce death!" She was then taken in the forest and tied to a tree near the bear's lair... and she was left in the gloomy wood. The girl managed to be release herself and escape in the neighbouring village (Sternberg 1936).

The most characteristic manifestations of the legend about the cosmic hunt-wedding were presented above.

However, it is necessary to point out that the second part of the legend about the descent of the sun elk to the underworld is by no means less important in reconstructing the ancient worldview. According to Rybakov, this version of solar myth on some Perm anthropomorphic clasps can be interpreted as the motif of the "travelling of the sun elk" to the western head of the lizard-like animal (Rybakov 1979: 13-19). A classic version of the travel is depicted on a metal clasp found in the village Nyrgynda (Udmurtia). The composition consists of three parts: the upper part displays three flying griffins under which there is, according to Spitsyn's colourful description

A huge, rather typical lizard-like animal, long, bended, with a short soft tail and short legs; there are the hair on its strong protruding bottom jaw and on its neck, the top part indented. On its torso, seven fishes symbolising water have been depicted. Sulde 'soul', 'spirit' with the legs bent forward is also very typical; its wings are long and tripartite, with eyes on it. Long elk heads extend from the head of the sulde and the head and sacrum of the lizardlike animal, with figures of shouting birds sticking out of them (quoted in Gribova 1975: 13).

The composition of the scene is similar to that described by Rybakov: here, too, female elks moving from the east to the west are repre- 
sented, with the only difference that the human face is shown only on the central figure. The number of elks corresponds to the three stages of the sun's movement: sunrise - the left figure, noon is shown by the elk with an anthropomorphic face, as it is in the best position for movement; the figure on the right corresponds to sunset, which is why the elk head is directly in front of the lizard-like animal's mouth in which one can see two already swallowed heads. The torso of the lizard-like animal is given as though in a crosssection, with seven fish visible inside, apparently referring to the metamorphoses which an individual undergoes in hell - i.e. the womb of the lizard-like animal. However near its tail, in the "easternmost" part of the inside of the lizard-like animal, the figures of fish are already depicted as having tiny elk heads, and behind the tail, like a stream of water, the same elk heads can be seen, ready to return to their place on the lizard-like animal's back. The majority of the elk heads indicate the various phases of the movement of the sun elk on its descent to the underworld. In the course of the plot only one character appears to evolve - while the elk, griffins and the lizard-like animal remain static, the elk itself moves from the east to the west and eventually inside the lizard-like animal's mouth.

The elk's descent to hell is by no means less important than the motif of the cosmic hunt in the solar myth. The absence of the sun elk in the sky results in the violation of the cosmic balance and causes fear of drowning in eternal gloom; therefore, the return of the elk in the sky should be perceived as a fortunate event. This applies particularly to the approach of vernal feast days, which involve rituals of greeting the sun. Even today the Orthodox Easter is accompanied with beliefs about how the sun "played" on the morning of Easter Sunday, which is why it was necessary to greet the rising sun. I. Georgi, who was a member of the 18th-century academic expedition team in the Perm area on the Chusovaya River, observed the celebration of the New Year on Easter Sunday. The celebration was held in a pagan sanctuary and included ritual sacrifice. According to I. Georgi, the participants in the ritual believed that the Easter Sunday was the day when God descended on earth, which they interpreted as the approach of spring, and addressed their prayers to the sun (quoted in Ignatov 2004: 102). As an additional example, it would be worth presenting a modern custom of the Salym Khanty, who were Christianised at the beginning of the 
19th century, to slaughter an elk for Easter and decorate the Easter table with the elk head. After a prayer addressed to the sun, the elk lips and tongue are eaten, and at sunrise, a salute shot from guns is given to greet the sun, which, according to the participants, "jumps" at this time (author's personal fieldwork materials). It seems that despite of a strong reduction, the same myth concerning the return of a divine elk from underworld can still be recognised in the Christian Easter tradition, and sacrifices are still performed. Apparently, this myth is identical to an ancient Greek myth about the return of Persephone from the underworld domain of Hades every spring, though the former is associated with fertility on earth. It seems that the secret travel of the sun or sun elk to the world of the dead proved even more mysterious than its visible run across the heavenly taiga. On a metal clasp described above, the elk in the womb of the lizard-like animal transforms into a fish. In general, fish is the most adequate symbol for the underworld-underwater movement beyond grave; therefore, the transformation of the sun into a fish is not surprising. The similar model has probably determined the conceptualisation of fish as the personified spirit of the dead in many cultures. In India, China and other areas, fish symbolises revival, therefore its image is used in funeral rituals (Tokarev 1982). In this connection it will be pertinent to remind about the Komi custom to prepare and serve fish, particularly, fish pie - cheri njanj at funerals. The linking of funeral-commemorative rituals with the travel of the sun beyond the grave is known in the mythologies of many people; this concept of the netherworld is particularly characteristic of the western world, where the sun sets. Taylor marks that in prehistoric beliefs, the course of the sun was identified with human life "with the charm of blossoming, the shine of midday and fading at sunset" (Taylor 1989: 280). In this connection, a burial should be oriented in the east to west direction "so that the head of the dead would be directed towards sunset" (Mazin 1984: 64) among the Evenks-Oroch, or "the burial of a corpse would face sunrise" among the Ob-Ugrians (Karjalainen 1996: 46).

In the legend, the "travelling" is by no means an insignificant concept symbolising the way to reach the netherworld. The nightly travel of the sun elk to the netherworld in the womb of a lizard-like animal is in this sense comparable to the post-mortal travel of the deceased: the dead should identify themselves with the Sun elk as 
best they can, and even become one. It is also possible that according to analogous beliefs, the best way of reaching the netherworld is through a ritual cremation, which was characteristic of many Finno-Ugric peoples in the prehistoric time, and has been followed by the Permyaks until, at least, the Ananin period. It is remarkable that the Finno-Ugrians and representatives of the medieval Perm culture at Vychegda also practiced inhumation next to cremation; in both funeral types the orientation of burials was predominantly north-south (45\%), with only $17.9 \%$ of tombs oriented west-east, the remaining burials were intermediate variants, remaining between meridional and latitudinal orientation: northwest-southeast, northeast-southwest (34\%); thus, the majority of burial places are oriented towards a water body (Saveleva 1987: 9-14). It is possible that the intermediate variants should either correspond to the latitudinal orientation, or they are an attempt to reconcile the two beliefs of the location of the netherworld - in the north or in the west. ${ }^{13}$ The simultaneous occurrence of these two types of burial (cremation and inhumation) in one society can be explained either by the existence of two different religious-mythological concepts of the netherworld in this society, or by the existence of one of type of a ceremony as a vestige. Saveleva supports the latter view, as she argues that the funeral ritual that developed aside strengthened the role of cremation (Saveleva 1987: 195), however, after the acceptance of Christianity, inhumation became the predominant type of burial.

Orientation of burials in meridional direction is associated with concepts of the world river as a path to the netherworld. This river joins the mythological South, which is associated not only with the upper courses of the river, but also the sky, the upper world, the abode of gods, which includes also the land of migrating waterfowl, with the North which, in turn, is associated with the underworld, the sea of the dead. In sky, the South and the North comprise the Milky Way, which is referred to as "the pathway of migratory birds" in all Finno-Ugric languages. This mythopoetical view of the world is also associated with a cosmogonic myth about two diving birds a duck and a diver which did not only generate the world but have an important role in the ideological systems of all the Uralic peoples (Napolskikh 1991: 74). This belief becomes manifest in the funeral ritual, which main purpose is the idea of the symbolical or 
actual departure of the deceased downstream the world river, which runs from south to north. A duck plays an important role in this belief, being the bearer or an embodiment of the dead soul. During the migration of waterfowl in the autumn, the duck spirit departs from the underworld to the upper world along the Milky Way, or "the pathway of ducks", and returns to the earthly world the same way. There can be no doubt that the custom of cremating the dead served one specific purpose - namely, imminent purification of the soul and its transforming into a duck. Probably, a more ancient version of the ritual involved the sending off of the deceased downstream the river, and during this "travel", the soul became gradually free from the physical world and transformed into a duck in the underworld. The same concept was symbolically expressed by inhumation, which gradually evolved into the disappearance of the deceased.

At the same time, the north-south axis divides the loci of the divine characters of the cosmogonic myth: the northern regions of gloom are attributed to the younger brother, and the light and heavenly south to the older brother, who resides there with his wife, the Goddess Mother, the matron of women in labour. In Komi mythology heaven and hell are divided between Jen and Omöl, brotherscontenders, the demiurgic war between whom caused the genesis of the world and determined the way it is now. Theonym Jen [jenm] corresponds to the concepts of 'god', 'sky'; jen-jenm 'god' - old Perm;/ Udmurt in-inm 'sky', inmar 'god'. - Common Perm; *jenm- 'god', 'sky' // Finnish ilma 'air', 'weather'; Ilmarinen 'the god of air' = Pre-Perm *ilma- 'air, the sky'.(Lytkin \& Guliaev 1999: 99). Omöl in Komi language means 'bad', 'nasty', 'thin', 'disgusting' (Komi-Russian dictionary 1961: 489), thus, he as though stands in contrast with Jen as 'the bad god' with 'good god'. Konakov assumes an etymological affinity of the term omöl with words omla, omlöd, omlög, meaning 'a river gulf', 'cove', 'a whirlpool', 'a deep place in the river', 'a failure', 'a hole at the bottom of the river', and also enj omla 'female uterus'(Lytkin \& Guliaev 1999: 205; Konakov 1990: 11). Its relation with elements of water is also speculated in a version of the origin of Omöl from the spittle of Jen (see Kuznetsova 1998: 63).

Semantic and linguistic analogues can be found also in the mythology of Karelians and Finns. Thus, according to E.G. Karhu's materi- 
als, Ilmarinen, the heavenly god-demiurge of a Finno-Ugrian origin, or ilma means 'air', 'air space', 'a firmament', 'weather'. The name Väinämöinen comes from the Finnish väinä 'the wide river with slow current'; the Livonian vena 'a mouth', 'passage'; the Estonian väin, vein 'a mouth', 'passage' (Karhu 1994: 75-76). Compare omlödcommon Perm * O $\eta_{3}$ - $l_{3}$ - 'a hole', 'furrow', 'a failure', 'a deepening'; PrePerm *a a - 'a deepening', 'an aperture' (Lytkin \& Guliaev 1999: 205). The relation of terms omlöd 'whirlpool' and enj omla 'uterus' is confirmed by cosmogonic semantics of water symbolizing the elemental chaos. According to S.A. Averintsev, water is the basic element and origin of procreation and generation and as such symbolises the feminine and masculine principle. "As a feminine principle, water functions as an analogue of a parent's bosom and a belly... At the same time, water is the male fecundating seed which makes the earth fertile" (Averintsev 1991: 240). Konakov correctly draws a parallel between the Komi omöl-omla and the Old Turkic umaj 'the patron goddess of childbirth, and also placenta, a womb, a uterus' (Konakov 1990: 11). In any case, except for linguistic affinity, the terms are connected by the common semantics of fertility, generation in the same way than in mythology the birth of the child from a parent's womb is equated to the birth of the world out of initial chaos. Here it is pertinent to mention F.V. Plesovski's hypothesis in which he claims that the origin of the term Omöl is related with the term Joma, which referred to female deity in the matriarchal period, and during patriarchy, the term transformed into a male deity. He believes that the term joma-omöl is an inverted loan from the name of the West-Finnish deity Jumal, Jumala (Plesovski 1972: 38) (cf. Kugu-Jumo, the demiurge of dualistic Mari cosmogony). It is believed that because of the taboo on saying out loud the name of the evil god in prehistoric times, the Komi adopted the name of the supreme god of the Finnish. According to the concise etymological dictionary of Komi language, joma means 'a witch', 'a baba-yaga'; joma Zyrian (juma Udora) < Balto-Finnic, cf. Finnish jumala 'the god', dialectal maajumala 'sorceress', 'a witch' (Lytkin \& Guliaev 1999: 100). Looking at another angle, it is believed that the concepts of "matriarchy" and "patriarchy" correspond to the cosmogonical idea of separating the masculine and female principles of the initially androgynous deity. Here it is possible to draw parallels with characters of the Indo-European mythology: Ymir, the forefather in the Scandinavian mythology (the word Ymir etymologically stands for 
the double, i.e. a bisexual essence, or twin), the Latvian field deity Jumis, lit. 'dual', 'a double embryo' (Meletinski 1991: 510), but most illustrative of the topic under discussion are the ancestral twins Yáma (from the Old Indian Yáma - which originally, apparently, meant 'twin') and Jami in Indian mythology (Grintser 1991: 682), and Iima (Avestin Iima, etymologically interpreted as 'twin', 'double') and Jema in the Iranian mythology (Lelekov 1991: 599). In the light of these typological conformities, Joma is the twin of Omöl, and, probably, this is a theonym of a female deity of fertility, which is equivalent to the concept of the Earth Mother (cf. the Turkic Umaj), the term omöl derived from Pre-Perm * $\alpha \eta \alpha$ - 'the deepening, an aperture' (Lytkin \& Guliaev 1999: 205) can be traced back to Finnish, where it means the bosom of a woman as a mythical original generating principle, the chaos. Thus, if the name of the first demiurge is connected with the concept of 'sky' and 'top' of 'light', or 'the upper top world', the second demiurge is initially connected with the concept of water, 'darkness', 'a female bosom' which semantically is identical with 'the bottom', 'the underworld'. The presence of a female deity in underworld, which would be the equivalent of Mother Earth in the earthly world, is quite common and has parallels in the mythologies of Siberian peoples. The two deities are opposed as the mothers of the upper spheres, who gives birth, and the underworld, which devours the souls of the dead. ${ }^{14}$ The need for the latter function is necessitated by the same need for clearing a soul from the sphere of the living, whereas the heavenly Goddess Mother, which appears in the shape of a duck or a goose, sends a soul-duck to the earth to give the souls to newborn children.

Thus, folklore and archaeological materials provide evidence of the existence of at least two basic mythological systems in the prehistoric mythology of the Komi, one of which is connected with a calendar legend about the hunt on a sun elk, and the other with a cosmogonic myth about a water bird extracting the earth from the bottom of the primordial ocean. Both mythologies originate in prehistoric times and reciprocally complete each other, despite of the obvious differences in worldview: the calendar myth about the cosmic hunt corresponds to the vertical cosmological line and the World Tree; the myth about a diving bird corresponds to the horizontal line and the World River. As a whole, the value of these systems lied in that they helped to conceptualise the mythological space 
and time in which the Komi people remained. Goddess Mother, whose iconography combines the attributes of bird, elk and bear, possibly serves as the point of contact. The main difference of the concept of Goddess Mother from the concept of the Earth Mother of the agrarian people is her originating and residing in heaven, whereas in the latter case, the Goddess Mother personifies the earth. The reasons and ways these systems interact, as well as the forms of religious worship of the characters of both mythological systems remain outside the scope of this article. In conclusion, it is possible to take a brief historical-genetic look into the development of the myths in these systems.

The theme of hunting an elk or deer is known almost by all peoples in Eurasia; however, its religious-mythological context in the form of a myth about the cosmic hunt has been best preserved in the Arctic region of Siberia. In the Komi areas, the earliest traces of cult worship of a deer have been discovered at the archaeological excavations at cave Medvezhy on Pechora (17,000 BC), during which the bones of animal origin, among which there were many reindeer antlers, were discovered. Archaeologist P. J. Pavlov explains it with their possible use for performing ritual ceremonies (Saveleva 2004: 18). Elk worship can be traced back to the early Middle Ages, when a representation of a zoomorphic cult object was found; in the 8th9 th century, this figure can no longer be found on cult object, having been replaced by figures of horses. Characteristically, this process occurred almost simultaneously throughout all the settled areas of the prehistoric world: this is evidenced by a single find in the famous kurgan of Pazaryk, where the horses, which pulled a funeral chariot, have been put on golden deer masks with antlers (Rybakov 1951: 7). Meanwhile, the changes have concerned all areas, and here, the characteristic identification of elk and horse can be found in the Finnish epic Kalevala, and figures of horses with deer antlers skipping on the field are represented of distaffs of Mezen. The myth disappears from religious use and only altered variants of the myth can be encountered in later phrases of folklore. As to the myth about a diving bird, the representation of the bird is revived on the linguistic level among the Uralic people. Traces of religious worship of waterfowl can be found throughout the vast area of Siberia and Europe from the Paleolithic period until the present time. Furthermore, its vivacity in various Christian Bogomile contaminations indicates that the plot of a myth has survived up to the present day. 


\section{Comments}

* Stefan Permski (born in 1345, died in 1396), or St. Stephen of Perm, converted the Komi people into Russian Orthodoxy (Editor's note).

1 The hunting calendar was based on the seasonal cycle of hunting.

2 "100 square kilometers of ground per hunter is required for providing sustenance" (Nikolaeva 1999: 73).

${ }^{3}$ Cf. "Unlike the Komi-Zyrians who were called "the forest people" and the inhabitants of "the forest kingdom", Russians were not familiar with the magic force of the forest. For a Russian the forest is a sacred place, which possesses powerful negative energy and thus life in the forest was reserved for the marginal members of the society, who had voluntarily or involuntarily left the "Russian world" (Terebikhin 1999: 34).

${ }^{4}$ Later, the same scenario repeated during the colonisation of Siberia by the Russian farmers. A. Gertsen describes the eastward migration as follows: "A handful of Cossacks and a few hundred homeless peasants overcame their fear for the ocean of ice and snow, and everywhere where this tired handful of them settled - in the frozen nature-forgotten steppes life began to boil, the land was covered with fields and herds, from the Perm region to the Pacific Ocean" ("Russia and Poland").

${ }^{5}$ Bylichka - legend, often memorate (Editor's note).

${ }^{6}$ Recorded in 1999 from G. M. Pashnin (1949) in village Lower Botch, Ust-Kuloms area, Komi Republic by students of the State University of Syktyvkar. ФАСГУ РФ 12-XI.

${ }^{7}$ Recorded from A. Y. Andreeva (1929) in village Berezniki, Priluzski area, Komi Republic in 2000 by P. F. Limerov, A. V. Paniukov, G. S. Saveleva ФФ ияЛИ ВФ 1506-43.

${ }^{8}$ Paraskeva - Orthodox saint, martyr, patron of female chores, fertility and marriage (Editor's note).

${ }^{9}$ Academician A. P. Okladnikov's poetic expression on this was the following: "In taiga, hunters figuratively represented the sun in the form of a live creature - a huge elk who travels all day across the sky and plunges in hell for the night, to the infinite sea of the underworld" (Okladnikov 1964: 59-60).

${ }^{10}$ A special tree, which was believed to correspond to the soul of a particular person (Editor's note). 
${ }^{11}$ In contemporary research, the legend about a female elk who steals the sun is more common; in this version the space hunter is compelled to kill it to return the sun to the earth. The author of this article believes that the given mythologema is a transformation of the most ancient version of the legend of the elk, which itself is the sun.

12 Pam, pan stood for a leader, a major, or a priest among the ancient Komi.

${ }^{13}$ According to the medieval European worldview the north and the west, the south and the east coincided: hence, paradise could be located in the east and "on midday" "in Eden", whereas hell was believed to be in the west "in the breathing sea" i.e. the Arctic Ocean. Further on this see Lotman 1996: 241.

${ }^{14}$ Cf. the Ket pair: Tomem, residing in heaven and identified with the sun and Hosedem, residing in the north, in the world of the dead (Ivanov \& Toporov: 1969: 152).

\section{References}

Aikhenvald, Aleksandra \& Petrukhin, Vladimir \& Khelimski, Evgeni 1982. K rekonstruktsii mifologitsheskikh predstavlenii finnougorskikh narodov [Reconstructing Finno-Urgic Mythology]. Balto-slavianskie issledovania = Baltu-slāvu pētījumi. Moscow: Nauka, pp. 162-192.

Anisimov, Arkadii F. 1959. Kosmologicheskie predstavlenia narodov Severa [Cosmological Conceptions of the Nordic Peoples]. Moscow \& Leningrad: AN SSSR.

Averintsev, Sergei A. 1991. Voda [Water]. Mify narodov mira. Moscow: Sovetskaia entsiklopedia.

Belitser, Vera N. 1958. Ocherki po etnografii narodov komi: XIX nachalo XX v. [Comments to Komi Ethnography: From the 19th to the Early 20th Century]. Trudy Instituta etnografii imeni N. N. MiklukhoMaklaia: Novaia seria, 45. Moscow: AN SSSR.

Charnolusski, Vladimir V. 1965. Legenda o olene-cheloveke [Legends about Human Reindeer]. Moscow: Nauka.

Eliade, Mircea 1999. Traktat po istorii religii [Treatise on the History of Religion]. St. Petersburg: Aleteia.

Florenski, Pavel A. 1976. Kult, religia, kultura [Cult, Religion, Culture]. Bogoslovskie trudy = Theological studies, 17. Moscow: Russkaia Pravoslavnaia Tserkov.

Golovnev, Andrei V. 1995. Govoriashchie kultury: Traditsii samodiitsev $i$ ugrov [Telling Cultures. The Traditions of the Samoyeds and Ugrians]. Ekaterinburg: Institut istorii i arkheologii Uralskogo odtelenia Ros. Akad. nauk. 
Gribova, Liubov S. 1975. Permskii zverinyi stil: Problemy semantiki [The Zoomorphic Style of Permyaks: Considerations of Semantics]. Moscow: Nauka.

Grintser, Pavel A. 1991. Iama [Cave]. Tokarev, Sergei A. (ed.). Mify narodov mira. Moscow: Akademii nauk, p. 682.

Ignatov, Mikhail D. 2004. Sobstvennoie imia "Zolotoi Baby" i etimologia gidronima "Ob" [The Golden Woman and Etymology of Hydronym Ob]. Art, 3, pp. 101-102.

Ivanov, Viacheslav V. \& Toporov, Vladimir N. 1969. Kommentarii k opisaniu ketskoi mifologii [Comments to the Ket Mythology]. Ivanov, Viacheslav V. \& Toporov, Vladimir N. (eds.). Ketskii sbornik = Studia Ketica. Moscow: Nauka.

Karhu, Eino 1994. Karelskii $i$ ingermanliandskii folklor $v$ istoricheskom osveshchenii [Historical Aspects of the Folklore of Karelia and Ingermanland]. St. Petersburg: Nauka.

Karjalainen, Kustaa Fredrik 1996. Religia ugorskikh narodov [Religion of the Ugric Peoples], 3. Tomsk: Tom.

Krinichnaia, Neonila A. 1987. Russkaia narodnaia istoricheskaia proza: Voprosy genezisa i struktury [Russian Historical Narrative Prose: Issues in Genesis and Structure]. Leningrad: Nauka.

Konakov, Nikolai D. 1990. Kalendarnaia simvolika uralskogo iazychestva (Binarnyi zoomorfnyi kod) [Symbolism of the Uralic Pagan Calendar (Binary Zoomorphic Code)]. Doklady na zasedanii prezidiuma Komi nauchn. tsentra UrO AN SSSR, 5 iulia 1990 = Kalendersymbolik des uralischen Heidentums. Seria preprintov "Nauchnye doklady", 243. Syktyvkar: Komi nauch. Tsentr UrO AN SSSR, pp. 11-19.

Konakov, Nikolai D. 1993. Ot Sviatok do sochelnika: Komi traditsionnye kalendarnye obriady [From Christmas to the Twelfth Night: Rituals in Komi Folk Calendar]. Syktyvkar: Komi knizhn. izd.

Konakov, Nikolai D. 1996. Traditsionnoe mirovozzrenie narodov komi: okruzhaiushchii mir: Prostranstvo i vremia [Traditional Worldview of the Komi: Space and Time]. Syktyvkar: KNC UrO RAN, pp. 90-190.

Konakov, Nikolai D. 1999a. Zarni An. Vlasov, Andrei N. et al. (eds.). Mifologia komi. Syktyvkar-Moscow: DIK Syktyvkar, p. 159.

Konakov, Nikolai D. 1999b. Ekologicheskie printsipy v komi mifoloogii [Ecological Aspects of Komi Mythology]. Vlasov, Andrei N. et al. (eds.). Mifologia komi. Syktyvkar-Moscow: DIK Syktyvkar, p. 80.

Kruglov, Aleksandr V. 1999. Lesnyie liudi [Forest People]. Nemushilova, Zoja I. (ed.). V debriakh Severa: Russkie pisateli XVIII-XIX vekov o zemle Komi. Syktyvkar: Komi knizhn. izd, pp. 348-445.

Kuznetsova, Vera S. 1998. Dualisticheskie legendy o sotvorenii mira $v$ vostochnoslavianskoi folklornoi traditsii [Dualistic Creation Myths in the Folklore of East-Slavonic People]. Novosibirsk: SO RAN. 
Lelekov, Leonid A. 1991. Iima. Tokarev, Sergei A. (ed.). Mify narodov mira. Moscow: Sovetskaia entsiklopedia, p. 599.

Lotman, Yuri M. 1996. Simvolicheskie prostranstva: Puteshestvie Ulissa v "Bozhestvennoi komedii" Dante. [Symbolic Spaces]. Vnutri mysliashchikh mirov: Chelovek, tekst, semiosfera, istoria. Moscow: Iazyki russkoi kultury, pp. 249-264.

Lytkin, Vasili I. \& Guliaev, Evgenii S. 1999. Kratkii etimologicheskii slovar komi iazyka [A Concise Etymological Dictionary of the Komi Language]. Syktyvkar: Komi knizh. izd.

Mazin, Anatoli I. 1984. Traditsionnye verovania $i$ obriady evenkovorochonov [Traditional Beliefs and Customs of the Evenki-Oroch]. Novosibirsk: Nauka.

Meletinski, Eleazar M. 1991. Imir. Tokarev, Sergei A. (ed.). Mify narodov mira. Moscow: Sovetskaia entsiklopedia, p. 510.

Napolskikh, Vladimir V. 1991. Drevneishie etapy proishozhdenia uralskoi iazykovoi semi: dannye mifologicheskoi rekontruktsii [Early Stages of the Development of the Uralic Language Family: Results of Reconstructing Mythology]. Prauralskii komogonicheskii mif. Materialy k serii "Narody Sovetskogo Soiuza" 5: Narody uralskoi iazykovoi semi. Moscow.

Nikolaeva, Nadezhda A. \& Saffronov, Vladimir A. 1999. Istoki slavianskoi $i$ evraziiskoi mifologii [Sources of Slavic and Eurasian Mythology]. Moscow: Belyi volk et al.

Okladnikov, Aleksei P. 1964. Olen Zolotye roga: Rasskazy ob okhote za naskalnymi risunkami [Elk with Golden Antlers: Stories of Hunting on Petroglyphs]. Moscow \& Leningrad: Iskusstvo.

Petrukhin, Vladimir Y. 2003. Mify finno-ugrov [Finno-Ugric Myths]. Mify narodov mira. Moscow: AST: Astrel.

Plesovski, Fedor V. 1972. Kosmogonicheskie mify komi i udmurtov [Cosmogonic Myths of the Komi and Udmurts]. Beznosikov, Jakov N. (ed.). Folklor $i$ etnografija komi. Trudy Instituta Jazyka, Literatury i Istorii, 13. Syktyvkar: AN SSSR, Komi filial, pp. 32-45.

Popov, Klavdi A. 1874. Zyriane i zyrianskii krai pri episkopakh Permskikh i zyrianskii iazyk [Zyryans and the Zyryan District under Perm Episcopacy and the Zyryan Language]. Izvestia obchestva liubitelei estestvoznanii, antropologii $i$ etnografii, 13 (2). Moscow.

Rybakov, Boris A. 1951. Prikladnoe iskusstvo i skulptura [Manufacture and Sculpture]. Voronin, Nikolai N. \& Karger, Mikhail K. (eds.) Istoria kultury Drevnei Rusi, 2: Obshchestvennyi stroi $i$ dukhovnaia kultura. Moscow \& Leningrad: AN SSSR, pp. 425-426.

Rybakov, Boris A. 1979. Kosmogonicheskaia simvolika "chudskikh" shamanskikh bliashek i russkikh vyshivok [Cosmogonic Symbols on the Metal Slabs of "Chude" Shamans and Russian Embroidery]. Finno-ugry 
$i$ slaviane: Trudy sovetsko-finskogo arkheologicheskogo simpoziuma. Moscow: Nauka.

Saveleva, Eleonora A. 1987. Vymskie mogilniki XI-XIV vv. [11th14th Century Burials in Vym]. Leningrad: LGUE.

Saveleva, Eleonora A. 2004. Arkhaichnye obchestva na territorii Komi kraia [Archaic Societies in the Komi District]. Smetanin, Aleksandr F. et al. (eds.). Istoria Komi $s$ drevneishikh vremen do kontsa XX veka. Syktyvkar: Komi knizh. izd.

Sidorov, Aleksei S. 1972. Ideologia drevnego naselenia Komi kraia [Ideology of the Prehistoric People of the Komi District]. Etnografia $i$ folklor komi. Trudy IaLI KFAN, 13. Syktyvkar, pp. 10-23.

Startsev, Georgi A. 1924. Revolutsia i zyriane (kultura i byt) [Revolution and the Zyryans (Culture and Lifestyle)]. Revolutsia $v$ derevne. Moscow \& Leningrad: Krasnaia nov.

Sternberg, Lev J. 1936. Pervobytnaia religia $v$ svete etnografii [Primitive Communal Religion in the Light of Ethnography]. Materialy po etnografii, IV. Leningrad: Iuan Ke.

Terebikhin, Nikolai M. Lukomorie: Ocherki religoznoi geosofii $i$ marinistiki Severnoi Rossii. Arkhangelsk: Izdatelstvo Pomorskogo Universiteta imeni M. V. Lomonosova.

Tokarev, Sergei A. 1986. Pozdnepervobytnaia obshchina zemledeltsevskotovodov i vysshikh okhotnikov, rybolovov i sobiratelei [Late Primitive Communal Society of Farmers-Breeders and Developed Society of Hunters, Fishers and Gatherers]. Istoria pervobytnogo obshchestva. Moscow: Nauka.

Tokarev, Sergei A. 1982. Ryba [Fish]. Sergei S. Tokarev (ed.). Mify narodov mira. Moscow: Sovetskaia entsiklopedia.

Taylor, Edward Burnett 1989. Pervobytnaia kultura [Primitive Culture]. Moscow: Politizdat.

\section{Tertiary sources}

Komi-Russian Dictionary 1961. Tumushev, Dmitri A. \& Kolegova, Nina A. \& Lytkin, Vasili I. (eds.). Komi-russkii slovar: Okolo 25000 slov. Moscow: GIS. 
